\title{
The Role of State Owned Enterprises in the Economic Liberalization of Liberia
}

\author{
Alieu Mohammed Massaley \\ Shanghai University, Shanghai, P. R. China
}

\begin{abstract}
Over the last three decades, the performance of state-owned-enterprises (SOEs) has been disappointing while the liberalization and privatization of SOEs has been treated with doubts. Policy makers around the world were left with few SOE policy options at a time when their performance caused not only administrative headaches but also political nightmare. The situation in Liberia is similar where a sizeable SOE sector has underperformed and the government has been hard pressed to find solutions to enhance their performances prior to the liberalization program. In this thesis, we examined whether the government imposition of hard budget constraint on SOEs has affected the operations of SOEs. We made a performance comparison of 20 Liberian SOEs between periods when they were under the Liberalization and privatization pressure during 2000-2017 and a period under which they were subject to little liberalization pressure. After conducting time-series and cross-sectional (TSCS) regression analysis with a dataset from 20 Liberian SOEs, we found there existed a statistically significant positive relationship between the Liberalization pressure and the operating efficiency of SOEs. This implies that while finding ways to Liberalize and or privatize SOEs, policymakers need to continually apply liberalization pressures on SOE managers in order to impose hard budget constraints on SOEs.
\end{abstract}

Keywords: Liberalization pressure, liberalization policy, soft budget constraint, operating performance, stateowned enterprise

DOI: $10.7176 / \mathrm{JESD} / 10-16-08$

Publication date: August $31^{\text {st }} 2019$

\section{Introduction}

Over the last 3 decades, many researchers have asserted that state-owned enterprises (SOEs) should be Liberalized or privatized while others have favored more gradual reform approaches. At the early stage of this debate, researchers were interested in (governance) ownership structure which they believed was the cause of SOEs' inefficiency. However, following decades of research, both advocates and opponents of liberalization have come to realize that the importance of managerial objectives and market structure. Accordingly, some argued that we need to pay closer attentions to how we could enforce performance-oriented goal and competitive market conditions on SOEs. While supporters of liberalization argue that liberalization is the only way to bring about changes in managerial goals and towards competitive environment, others maintain that it can be accomplished by more gradual approaches. Stuck in the controversy, policy makers were often left with little policy options but to continue with traditional SOE policies.

SOEs can also be referred to as state owned entities or companies, which according to Bozec et, al., (2002) are legal entities that tend to carrying out business activities on behalf of the state. SOEs can sometimes be referred to as state-owned companies, state- owned entities, or state-owned enterprises. They all are government owned business entities or publicly owned companies created by government to undertake commercial actions on the behalf of government (Friedmann W. and Garner J. F., 1970). State-owned enterprises (SOEs) are common in many countries and more so in conflict-prone countries like Liberia.

When one is defining SOEs one has to differentiate between commercial SOEs and non-commercial SOES. SOEs can sometimes be referred to as state-owned companies, state- owned entities, or state-owned enterprises. They all are government owned business entities or publicly owned companies created by government to undertake commercial actions on the behalf of government (Friedmann W. and Garner J. F., 1970). A non-commercial SOE is a company created and solely owned by government to carry out particular functions on behalf of the government with the main aim of providing goods and services to its citizens (OECD, 2005).

In an environment like that, the defined economic and political systems wherein the SOEs exist often show similar interests in terms of what the participants of the conflict and those hoping to end the conflict want. They are also seen as essential providers of service. Since the goal is to achieve stability, it is imperative for SOEs to become productive (Efird, 2010). One way of doing that is to implement strategic management which refers to initiatives an organization takes to maximize its resources and to grow its business. These are called the strategies and they involve financial planning, human resources management or focusing on implementing a mission statement (Christiansen, H. 2011). Strategic management is vitally important yet difficult to accomplish without defining a clear set of goals for the operations of the organization. SOEs have to know what their core competencies are as well as their strengths in the marketplace. Many nations with transition economies are attempting to develop their national competitiveness through such processes as privatization of state-owned enterprises (SOEs) and/or 
the use of economic liberalization (e.g. lessening of tariffs, industry regulations, etc.) to spur economic growth and development as a complement to privatization. As shown by Russia and other countries that continue to falter in their transition process (Gaddy and Ickes 1999, Kingston-Mann 1999; Chen, V.Z. et al. 2018), some countries are missing key factors that are critical to their successful transition.

Likewise, scholars who focus on the market shock approach (i.e. The immediate introduction of vast privatizations of SOEs and economic liberalization of markets (Fourie, D.J., 2001) maintain that privatization and economic liberalization are one component as extensive levels of privatization of SOEs are executed in association with relatively moderate levels of economic liberalization. They have to identify areas for improvement and set goals and objectives based on those weaknesses. For example, SOEs might lack presence in the worldwide web and they are not utilizing the power of the Internet to reach out to the constituents they are serving. One of their goals, for example, should be to introduce an online trading platform within the next six months. More importantly, the goals that are set should be measurable, specific and have a time frame attached to them. Setting goals in this way helps SOEs strategically position their services for future success (Sutiyono, W. 2007).

Liberia has nearly 20 State-Owned Enterprises (SOE's) most of which are government-owned (whollyowned), with a work force of more than 10,000 people. The SOE's operate in several sectors including port services, airport and civil aviation, electricity supply, oil and gas, water and sewage, agriculture and forestry, maritime, petroleum importation and storage and information/communications services. The SOE's are not independent as their boards are governed by government ministries with board members appointed by the president. The SOE sector remains a key part of Liberia's economic development agenda and is guided by the Public Financial Management (PFM) Law of 2009 which sets out rules governing SOE management and operations.

While some SOEs are functional and contribute to the national budget, others exist statutorily and have remained non-functional over the years. Unfortunately, there are no established programs or policies for privatization, though the government has commissioned a review of the SOE's to determine their viability and functional relevance with an eye towards possible privatization in the future. While the study validates many SOE's, it finds that a number of them have become dysfunctional and a waste of resources to the government. In 2016, the Liberian government announced its intention to entirely outsource, and therefore privatize, its public pre-primary and primary schools to private actors, through a Public Private Partnership (PPP) arrangement. The government is currently developing a harmonized public private partnership policy (State Department Office, 2017).

The situation in Liberia is similar where a sizeable SOE sector has been criticized for its performance and the government has been hard pressed to find solutions to enhance their performances prior to the liberalization program.

We made a performance comparison of 20 Liberian SOEs between periods when they were under the liberalization and privatization pressure during and a period under which they were subject to little privatization pressure. After conducting time-series and cross-sectional (TSCS) regression analysis with a dataset from 20 Liberian SOEs, we found there existed a statistically significant positive relationship between the liberalization pressure and the operating efficiency of SOEs. During the period when the government imposed more tight fiscal control on SOEs while implementing liberalization and privatization program SOE performance tended to be better than a period under which SOEs were rarely subject to restructuring programs. This phenomenon gives us significant insights on the behavior of SOEs and the strategic approach to SOEs policy.

In lieu of the above, the researcher invested the following:

- The reasons for establishment of State-Owned Enterprises in Liberia

- The level of economic liberalization of Liberia

- The relationship between SOEs and economic liberalization in Liberia

\section{Hypothesis Development}

As mentioned above, the correlation between performance and liberalization pressure is found in several SOEs. To test the correlation between the performance of SOEs and liberalization or privatization pressure, this thesis supposes some hypotheses (H1-H4). SOEs' managers and employees prefer their company to stay in the public sector because there exist rent: long tenure, lower work intensity, and better pay. When they are faced liberalization or privatization pressure, they are subject to hard budget constraint. In addition, they are pressed to improve financial and operating efficiency in order to maximize sales proceeds. That is, when people show interests in the efficiency of SOEs, social (and economic) monitoring is strengthened and this, in turn, hardens the budget constraint, having an influence on SOE's efficiency. Hence, we expect that the liberalization and privatization pressure to have positive influence on several efficiency variables.

$\mathbf{H}_{1}$ : Liberalizing pressure improves profitability.

$\mathbf{H}_{2}$ : Liberalizing pressure improves operating performance.

$\mathbf{H}_{3}$ : Liberalizing pressure reduces employment.

$\mathbf{H}_{4}$ : Liberalizing pressure reduces leverage level. 


\section{Data}

To test these four hypotheses, we collected panel data of 20 SOEs over 18 year period between 2000 and 2018. The observed companies contain most large-sized SOEs in Liberia. The data include annual financial statements and employment statistics, most of which were made available on the websites of SOE and Table 1 shows the average statistics for the year 2018. Other variables including macroeconomic ones were acquired from the National Statistics of Liberia Office.

Table 1 Summary Statistics of defendant variables in 2018

\begin{tabular}{|c|c|c|c|c|c|c|c|}
\hline Year & Proxy & $\mathrm{N}$ & Mean & Median & SD & Min & Max \\
\hline 2018 & ROS & 18 & 0.007117 & 0.04269 & 0.172476 & -0.54025 & 0.18877 \\
\hline & ROE & 18 & 0.062191 & 0.0485 & 0.102089 & -0.18403 & 0.3630 \\
\hline & ROA & 18 & 0.020048 & 0.01283 & 0.053569 & -0.13266 & 0.15133 \\
\hline & SAEFF & 18 & 1111.63 & 435.5505 & 1824.8 & 1.29771 & 7483.45 \\
\hline & NIEFF & 18 & 49.99536 & 12.60144 & 114.0151 & -229.613 & 352.0596 \\
\hline & SAL & 18 & 29938.11 & 3566.81 & 59462.84 & 9.57422 & 257634.5 \\
\hline & EMPL & 18 & 2776.68 & 1156.5 & 4402.11 & 801 & 21174 \\
\hline & LEV & 18 & 0.607928 & 0.611655 & 0.35965 & 0.137 & 1.74698 \\
\hline
\end{tabular}

\section{Variables Selection}

Variables 'profitability', 'operating efficiency', 'employment' and 'leverage' use the same definition as in most papers on SOE performance, including Magginson et al. (1994), Wei et al. (2003), and Kim (2007), (Table 2). The dependent variable, 'Liberalization pressure', is defined as a dummy variable related with the type of administration: the Hellen Johnson's administration 'with' Liberalization pressure is defined as 1 and the George's administration 'without' Liberalization pressure as 0 .

\section{Regression Model Specification}

To control the macroeconomic factors and other company characteristics, time series and cross section (TSCS) regression is needed. The regression analyzed panel data which vary through time and place. It is very important to understand the dynamics that the two dimensions of the data are analyzed at once. The TSCS regression is one of the best ways to estimate the causality of variables, and this paper also uses this methodology. The regression model is as follows.

$$
\mathrm{DV}_{\text {it }}=\mathrm{PP}_{\mathrm{t}}+\mathrm{ME}_{\mathrm{t}}+\mathrm{EC}_{\mathrm{it}}+\mathrm{e}
$$

$\mathrm{DV}_{\text {it }}$ demonstrates dependent variable of SOE $\mathrm{i}$ in year $\mathrm{t} . \mathrm{PP}_{\mathrm{t}}$ is the experimental variable, the privatizing pressure dummy in year t. $\mathrm{ME}_{\mathrm{t}}$ demonstrates macroeconomic control variables in year $\mathrm{t}$. And $\mathrm{EC}_{\mathrm{it}}$ control for enterprise characteristics in year $t$.

Table 2 Variable Description and Testable Prediction

\begin{tabular}{|c|c|c|}
\hline Characteristics & Proxies & Predicted relationship \\
\hline \multirow[t]{3}{*}{ Profitability } & Return on Sales $($ ROS $)=$ Net income $/$ Sale & $\mathrm{ROS}_{\mathrm{JON}}>\mathrm{ROS}_{\mathrm{GEO}}$ \\
\hline & Return on Assets $($ ROA) $=$ Net income $/$ Total Asset & $\mathrm{ROA}_{\mathrm{JON}}>\mathrm{ROA}_{\mathrm{GEO}}$ \\
\hline & Return on Equity (ROE) = Net income / Equity & $\mathrm{ROE}_{\mathrm{JON}}>\mathrm{ROE}_{\mathrm{GEO}}$ \\
\hline \multirow[t]{2}{*}{$\begin{array}{l}\text { Operating } \\
\text { Efficiency }\end{array}$} & Sales Efficiency $($ SALEFF $)=$ Real Sale $/$ Employment & $\begin{array}{l}\text { SALEFF }_{J O N}> \\
\text { SALEFF }_{\mathrm{GEO}} \\
\end{array}$ \\
\hline & $\begin{array}{c}\text { Net income efficiency (NIEFF) }=\text { Net income } / \\
\text { Employment }\end{array}$ & $\mathrm{NIEFF}_{\mathrm{JON}}>\mathrm{NIEFF}_{\mathrm{GEO}}$ \\
\hline Output & Real Sales $($ SAL) $=$ Nominal Sale / GDP Deflator & $\mathrm{SAL}_{\mathrm{JON}}>\mathrm{SAL}_{\mathrm{GEO}}$ \\
\hline Employment & $\begin{array}{c}\text { Total Employment (EMPL) = Total Number of } \\
\text { Employment }\end{array}$ & $\mathrm{EMPL}_{\mathrm{JON}}<\mathrm{EMPL}_{\mathrm{GEO}}$ \\
\hline Leverage & Debt to Asset $(\mathrm{LEV})=$ Total Debt $/$ Total Asset & $\mathrm{LEV}_{\mathrm{JON}}<\mathrm{LEV}_{\mathrm{GEO}}$ \\
\hline
\end{tabular}

* This variable description mainly modified Magginson et al. (1994) and Kim (2007). Note JON is the period of liberalization pressure during Hellen Johnson's rule and GEO is a period of less liberalization pressure during George's rule.

\section{Analysis of Results and Discussion}

This section presents the findings of the research as well as their analysis and interpretation. Tables are used to illuminate the meaning of the data presented. The findings presented in the tables are further explained to equip the reader with clear picture and understanding of the phenomenon under analysis. 


\section{Regression Results of Time-Series data \\ ○ Profitability}

Profitability is defined in three popular terms, return on sales (ROS), return on assets (ROA), and return on equity (ROE). This paper estimated causality with 3 models for each proxy, 9 models in total. According to the analysis, we found that there is no statistically significant relationship between liberalization pressure and profitability (Table 3). As we can see from the equation, there are two ways to improve profitability; i ) increase net income and/or ii ) reduce sales, asset or equity. But it is very difficult to increase net income without technical advances or exogenous factors and to reduce the equity or assets because of institutional constraints. Accordingly, although the liberalization and privatization pressure hardened budget constraint, SOEs rarely have time and methodology to improve profitability in short term.

Table 3 TSCS Regression Output 1: Profitability

\begin{tabular}{|c|c|c|c|c|c|c|c|c|c|}
\hline & \multicolumn{9}{|c|}{ Profitability } \\
\hline & Model1 & Model2 & Model3 & Model4 & Model5 & Model6 & Model7 & Model8 & Model9 \\
\hline $\begin{array}{l}\text { Dependent } \\
\text { Variable }\end{array}$ & ROS & ROS & ROS & ROE & ROE & ROE & ROA & ROA & ROA \\
\hline Intercept & $\begin{array}{c}0.43 \\
(0.70)\end{array}$ & $\begin{array}{c}0.45 \\
(0.69)\end{array}$ & $\begin{array}{c}0.38 \\
(0.74)\end{array}$ & $\begin{array}{l}27.50 \\
(0.15)\end{array}$ & $\begin{array}{l}28.07 \\
(0.14)\end{array}$ & $\begin{array}{l}27.92 \\
(0.14)\end{array}$ & $\begin{array}{l}-0.36 \\
(0.20)\end{array}$ & $\begin{array}{l}-0.35 \\
(0.22)\end{array}$ & $\begin{array}{l}-0.36 \\
(0.21)\end{array}$ \\
\hline $\begin{array}{l}\text { Liberalizing } \\
\text { Pressure }\end{array}$ & $\begin{array}{c}0.02 \\
(0.78)\end{array}$ & $\begin{array}{c}0.02 \\
(0.79)\end{array}$ & $\begin{array}{c}0.02 \\
(0.78)\end{array}$ & $\begin{array}{l}-0.96 \\
(0.57)\end{array}$ & $\begin{array}{l}-0.97 \\
(0.57)\end{array}$ & $\begin{array}{l}-0.97 \\
(0.57)\end{array}$ & $\begin{array}{l}0.025 \\
(0.32)\end{array}$ & $\begin{array}{l}0.025 \\
(0.33)\end{array}$ & $\begin{array}{l}0.025 \\
(0.32)\end{array}$ \\
\hline $\begin{array}{c}\text { GDP } \\
\text { Deflator }\end{array}$ & $\begin{array}{l}-0.005 \\
(0.65)\end{array}$ & $\begin{array}{l}-0.005 \\
(0.63)\end{array}$ & $\begin{array}{l}-0.004 \\
(0.68)\end{array}$ & $\begin{array}{l}-0.27 \\
(0.13)\end{array}$ & $\begin{array}{l}-0.27 \\
(0.13)\end{array}$ & $\begin{array}{l}-0.27 \\
(0.13)\end{array}$ & $\begin{array}{l}0.003 \\
(0.19)\end{array}$ & $\begin{array}{l}0.003 \\
(0.20)\end{array}$ & $\begin{array}{l}0.003 \\
(0.19)\end{array}$ \\
\hline GDP & $\begin{array}{c}0.00 \\
(0.54)\end{array}$ & $\begin{array}{c}0.00 \\
(0.60)\end{array}$ & $\begin{array}{c}0.00 \\
(0.64)\end{array}$ & $\begin{array}{l}0.0003 \\
(0.32)\end{array}$ & $\begin{array}{c}-0.0004 \\
(0.29)\end{array}$ & $\begin{array}{c}0.0004 \\
(0.30)\end{array}$ & $\begin{array}{c}0.00 \\
(0.61)\end{array}$ & $\begin{array}{c}0.00 \\
(0.62)\end{array}$ & $\begin{array}{c}0.00 \\
(0.96)\end{array}$ \\
\hline Asset & & $\begin{array}{l}0.000 \\
(0.43)\end{array}$ & & & $\begin{array}{l}0.000 \\
(0.90)\end{array}$ & & & $\begin{array}{l}0.000 \\
(0.71)\end{array}$ & \\
\hline Employment & & & $\begin{array}{l}0.000 \\
(0.88)\end{array}$ & & & $\begin{array}{l}0.000 \\
(0.97)\end{array}$ & & & $\begin{array}{l}0.000 \\
(0.96)\end{array}$ \\
\hline Debt & & $\begin{array}{c}0.00 \\
(0.74)\end{array}$ & $\begin{array}{c}0.00 \\
(0.48)\end{array}$ & & $\begin{array}{c}0.00 \\
(0.76)\end{array}$ & $\begin{array}{c}0.00 \\
(0.74)\end{array}$ & & $\begin{array}{c}0.00 \\
(0.75)\end{array}$ & $\begin{array}{c}0.00 \\
(0.94)\end{array}$ \\
\hline $\begin{array}{l}\text { Adjusted } \\
\mathbf{R}^{2}\end{array}$ & 0.0049 & 0.0108 & 0.0081 & 0.0132 & 0.0145 & 0.0144 & 0.008 & 0.0087 & 0.0081 \\
\hline
\end{tabular}

○ Operating Efficiency

Operating efficiency is defined in two terms: sales efficiency and net income efficiency. These are similar with labor productivity often used in economics. This paper estimated causality with 3 models for each proxy, 6 models total. According to the models 1, 2, 3 in table 3, operating efficiency (sales efficiency) is significantly higher under the privatization pressure. Sales efficiency is defined as sales per employee, and the two components are under the control of SOE managers. In the Liberian SOE sector, it is hard to lay off workers but recommending or giving incentives to voluntary retirement works as a good tool for managers. Sales can also increase when managers and employees work harder and provide better services. That is, under the liberalization pressure, smaller organization with more intensive labor produces more output.

Labor unions and some experts assert that restructuring reform often deteriorates the quality of products and services, stability and safety, but people as taxpayers want to tighten the slack. Moreover, if most products and services are provided as before, people would naturally prefer privatization and smaller SOEs. This is the basis for the current liberalization argument in Liberia. Thus, we can verify that the liberalization pressure had a positive influence on the operating performance of SOEs.

Moreover, although it is not statistically significant, net income efficiency is also higher under liberalization pressure. It supports the general hypothesis on the budget constraint (Kornai: 1980, 1992). 
Table 3 TSCS Regression Output 2: Operating Efficiency

\begin{tabular}{|l|l|l|l|l|l|l|}
\hline & \multicolumn{6}{|c|}{ Operating Efficiency } \\
\hline & Model1 & Model2 & Model3 & Model4 & Model5 & Model6 \\
\hline $\begin{array}{l}\text { Dependent } \\
\text { Variable }\end{array}$ & SALEFF & SALEFF & SALEFF & NIEFF & NIEFF & NIEFF \\
\hline Intercept & -4998.96 & -4900.31 & -4675.65 & -277.206 & -298.992 & -294.854 \\
& $(0.0092)^{* * *}$ & $(0.0089) *$ & $(0.0128)^{* *}$ & $(0.5521$ & $(0.5210)$ & $(0.5239)$ \\
\hline $\begin{array}{l}\text { Liberalizing } \\
\text { Pressure }\end{array}$ & 450.692 & 443.1822 & 427.286 & 45.9028 & 45.6854 & 44.0508 \\
\hline GDP Deflation & $(0.0081)$ & $(0.0071)^{* * *}$ & $(0.0094)^{* * *}$ & $(0.2737)$ & $(0.2731)$ & $(0.2884)$ \\
& 51.1486 & 49.8501 & 49.2135 & 2.5552 & 2.7427 & 2.8446 \\
& $(0.0048)^{* * *}$ & $(0.0049)^{* * *}$ & $(0.0053)^{* * *}$ & $(0.5674)$ & $(0.5393)$ & $(0.5207)$ \\
\hline GDP & 0.0350 & 0.0229 & 0.0251 & 0.0036 & 0.0016 & 0.0004 \\
& $(0.3438)$ & $(0.5339)$ & $(0.4930)$ & $(0.6913)$ & $(0.8628)$ & $(0.9630$ \\
\hline Asset & & 0.0000 & & & 0.0000 & \\
& & $(0.1181)$ & & & $(0.4580)$ & \\
\hline Employment & & & -0.0452 & & & -0.0045 \\
& & & $(0.0664)^{*}$ & & & $(0.2277)$ \\
\hline Debt & & 0.0000 & 0.0000 & & 0.0000 & 0.0000 \\
& & $(0.3342)$ & $(0.1299)$ & & $(0.9181)$ & $(0.0442)^{* *}$ \\
\hline Adjusted $\mathbf{R}^{\mathbf{2}}$ & 0.093 & 0.1104 & 0.1144 & 0.0058 & 0.0204 & 0.0247 \\
\hline
\end{tabular}

$\circ$ Output, Employment, and Leverage

Many previous studies also studied the impact on output, employment, and leverage. But in our TSCS regression output we found no statistically significant results. Although it is not significant, real sales (SAL) is fairly higher under the Hellen Johnson's administration.

Table 4TSCS Regression Output 3: Output, Employment, and Leverage

\begin{tabular}{|c|c|c|c|c|c|c|c|}
\hline & \multicolumn{7}{|c|}{ Output, Employment, and Leverage } \\
\hline & Model1 & Model2 & Model3 & Model4 & Model5 & Model6 & Model7 \\
\hline $\begin{array}{l}\text { Dependent } \\
\text { Variable }\end{array}$ & SAL & SAL & SAL & EMPL & EMPL & LEV & LEV \\
\hline Intercept & $\begin{array}{l}-39526.4 \\
(0.3067)\end{array}$ & $\begin{array}{l}-12040.8 \\
(0.6944)\end{array}$ & $\begin{array}{l}-17148.3 \\
(0.6599)\end{array}$ & $\begin{array}{l}14471.24 \\
(0.0174)^{* *}\end{array}$ & $\begin{array}{l}7145.846 \\
(0.1324)\end{array}$ & $\begin{array}{l}1.1547 \\
(0.0056)^{* * * *}\end{array}$ & $\begin{array}{l}1.0512 \\
(0.0122)\end{array}$ \\
\hline $\begin{array}{l}\text { Liberalizing } \\
\text { Pressure }\end{array}$ & $\begin{array}{l}4792.54 \\
(0.1557)\end{array}$ & $\begin{array}{l}3646.364 \\
(0.1778)\end{array}$ & $\begin{array}{l}3433.967 \\
(0.3166)\end{array}$ & $\begin{array}{l}-588.999 \\
(0.2718)\end{array}$ & $\begin{array}{l}-445.799 \\
(0.2871)\end{array}$ & $\begin{array}{l}-0.0054 \\
(0.8833)\end{array}$ & $\begin{array}{l}-0.0012 \\
(0.9745)\end{array}$ \\
\hline $\begin{array}{l}\text { GDP } \\
\text { Deflator }\end{array}$ & $\begin{array}{l}4292925 \\
(0.2326)\end{array}$ & $\begin{array}{l}117.5364 \\
(0.6857)\end{array}$ & $\begin{array}{l}280.3805 \\
(0.4458)\end{array}$ & $\begin{array}{l}113.335 \\
(0.0480)^{* *}\end{array}$ & $\begin{array}{l}-38.8286 \\
(0.3884)\end{array}$ & $\begin{array}{l}-0.0055 \\
(0.1610)\end{array}$ & $\begin{array}{l}-0.0047 \\
(0.2336)\end{array}$ \\
\hline GDP & $\begin{array}{l}2.1241 \\
(0.0043) * * *\end{array}$ & $\begin{array}{l}1.1421 \\
(0.0621)^{*}\end{array}$ & $\begin{array}{l}1.7512 \\
(0.0235)^{* *}\end{array}$ & $\begin{array}{l}0.1063 \\
(0.3649) \\
\end{array}$ & $\begin{array}{l}-0.0394 \\
(0.6762) \\
\end{array}$ & $\begin{array}{l}0.0000 \\
(0.3566)\end{array}$ & $\begin{array}{l}0.0000 \\
(0.4063) \\
\end{array}$ \\
\hline Asset & & $\begin{array}{l}0.0035 \\
(<.0001)\end{array}$ & & & $\begin{array}{l}-0.0003 \\
(<.0001)\end{array}$ & & \\
\hline Employment & & & $\begin{array}{l}-2.5461 \\
(<.0001)^{* *} \\
*\end{array}$ & & & & $\begin{array}{l}0.0000 \\
(0.1224)\end{array}$ \\
\hline Debt & & $\begin{array}{l}-0.0036 \\
(<.0001)\end{array}$ & $\begin{array}{l}0.0001 \\
(0.0017)^{* * *}\end{array}$ & & $\begin{array}{l}0.0006 \\
(<.0001)\end{array}$ & & \\
\hline Adjusted R ${ }^{2}$ & 0.1567 & 0.5197 & 0.2315 & 0.0215 & 0.4336 & 0.0227 & 0.0336 \\
\hline
\end{tabular}

\section{Discussion of the Result with Soft Budget Constrain Perspective}

\section{- Soft Budget Constraint}

Why did Operating Efficiency Improve under Liberalization and Privatizing Pressure? There can be many answers, but this thesis suggests an explanation based on the hardening of budget constraint. The key concept, 'Soft budget constraint' comes from the studies on transition economies. Before the change, the fundamental feature of a centralized (planned) economy is the dominance of the state sector. A large body of evidence documents that a major problem in socialist transition economies has been a lack of financial discipline in this sector. The lack of discipline stems from the unenforceability of bankruptcy threats, together with various subsidies, credits, and price-supports, implying, as Kornai $(1979,1980,1992)$ recognized, that state firms are subject to soft budget constraints. It directly influences the efficiency of the state sector through their effect on the expectations of SOEs managers (Maskin and $\mathrm{Xu}, 2001$ ).

Kornai suggested four different means to soften budget constraint of the firm. 
(1) 'Soft subsidies' granted by national or local governments. The subsidy is soft if it is negotiable, subject to bargaining, lobbying, etc. The subsidy is adjusted to past, present or future cost overruns.

(2) 'Soft Taxation.' The attribute soft does not refer to the rate of taxation. Even with a low tax rate the taxation system can be hard, if rules are uniform, fixed for a long period and the payment of taxes rigorously enforced. In contrast taxation is soft, even with a high tax rate, if the rules are negotiable, subject to bargaining, political pressures. The tax rates are not uniform, but almost tailor-made according to the financial situation of different sectors or different regions or different forms of ownership. The fulfillment of tax obligations is not strict; there are leaks, ad hoc exemptions, postponements, etc.

(3) 'Soft credit.' Again softness does not refer to the magnitude of the interest rate. The credit system can be hard even with a low interest rate (provided that the credit market generates a low rate), if the fulfillment of credit contracts is strictly enforced. The creditor lends money expecting discipline in debt service and not for the sake of assistance to an ailing firm which will not be able to service its debt. Enforcement of the credit contract continues to the bitter end; harsh sanctions in the case of insolvency, including receivership, bankruptcy, forced merger, sell-out or other similar legal means. In contrast, the credit system can be soft even with high interest rates, if the fulfillment of a credit contract is not enforced, unreliable debt service is tolerated and postponement and rescheduling are in order. Soft credit is used to assist firms in great and chronic financial trouble, without real hope of repayment of the debt.

(4) 'Soft administrative prices.' This can be applied in the case when the price is not set by a free contract seller and buyer, but by some bureaucratic institution. The administrative price is hard if, once set, it restricts expenditure and does not automatically adjust to cost increases. An administrative price is soft if it is set according to some permissive "cost plus" principle that automatically adjusts prices to costs.

- Liberalization Pressure Hardens the Budget Constraint

The Liberian SOEs were previously faced with soft budget constraints, and as a result, the inefficiency of the company was embedded in the structure. However, we found that liberalization and privatization pressure improved operating performance significantly. Thus, it is possible that the liberalization pressure hardened the budget constraint and it affected SOEs' economic performance. Managers perceive liberalization pressure as a threat which can block all sources of the soft budget constraint. In this case, the threat has lower probability but high penalty. When it is expensive or impossible to monitor and uncover the bad, authority have an alternative to increase the penalty to prevent the bad. The sources can be interpreted as the rent of SOEs, and the interest groups struggle to maintain it. These rent-seeking behaviors generally brought corruption or illegal activities in the past, but it can also be a great incentive to perform efficiently in good anti-corruption and court system, and this incentive strongly activates under the privatizing pressure. However, as mentioned in the Chapter I, this pressure cannot improve their performance to the privately-owned enterprises level because small amount of rent cannot disappear because it works as an incentive.

State-owned enterprises often have been in the spotlight over the performance of managers and their employees. As business organization owned by the government, state-owned enterprises faced with the bureaucratic work patterns. It caused the state-owned companies faces challenges in the procedure (Sari, 2011). As new paradigm of better performance, SOEs must improve their internal control in accordance with the conditions of the working environment.

Internal control levels are weak and allow the fraud occurred. Internal control level consists of work ethics, audit, risk management, communication and monitoring and evaluation (Abbott, 2002). How far the quality of internal control level can be seen from the readiness of state-owned enterprises in preparing these components? Besides of the well-being and comfort of work also determines how strongly employees of state-owned companies build performance (Nguyen, 2011). Sometimes there is a perception and motivation which affect their performance.

Human resource is an important factor in achieving the goal of efficient and effective SOEs (Sutiyono, 2007). SOE administrators need to measure employee productivity associated with the job description, key result areas, and Key Performance Indicators. This method also aims to determine the indicators that led to increased individual performance through achievement planning and standards of achievement. In addition, it also needs standardization of the internal and external goal of the SOEs (Hervani, 2005). The success of SOE internal and external goals is not entirely dependent on the administrators and the management, but also employee involvement in the activities and achievement to fulfill the goals. Therefore, employees are important factor for the successful SOEs which should be developed by placing proper position of excellence employees in accordance with its capabilities and expertise (the right man on the right place).

Efforts to achieve the objectives of SOEs can be realized through increased productivity. Their higher productivity will create efficient operation of SOEs. However, administrators as the SOEs managers must also anticipate all the challenges and obstacles in the internal and external issues to improve the efficiency (Kephart, 2003).

Since SOEs is bureaucratic company, it has to adapt to the regulation and authority while making changes in the workings of company to respond to the needs of employees and customers. In addition, it also has to 
reformulate their work pattern to develop initiative and creativity to think, and utilize their potentials which impact on the government revenue. Therefore, the state is required to be innovative and creative. However, what they do is still far from their competence as professional public servants who are characterized by many problems, e.g., bureaucratic cases, violations of code of ethics and indiscipline behaviors especially related to risk management and performance evaluation.

For the code of ethics, it is showed from many cases conducted by many employees of Accounting and Reporting Section especially on how they doing bookkeeping documentation. Sometimes the most problem happened is the late reporting was made. In addition, in performing the duties and functions, there are various difficulties on the complexity of the structure of human resources and budgeting of their operation. Furthermore, SOEs also face problems such as fluctuated productivity due to workplace migration and also the structural changes of the employees due to restructuring policies like liberalization which impact on the loss of great talent in their enterprises.

The restructuring process will impact on the new arrival of employees group and finally it creates overlapping of authority (Massey, 2013). In addition, the different employees may have different responsibility and expertise which makes them difficult to build unified communications (Nonaka, 2000). Exacerbated by unstandardized working conditions and management policies, it impact on the difficulties in the human resources measurement to fulfill the general objectives of SOEs.

\section{Concluding Remarks}

The research contributes to trade literature by exploring the relationship between state-owned enterprises, liberalization pressure, and privatization in the Liberian context. Theories and literatures were reviewed to develop a suitable model for Liberia's liberalization pressure and the model was developed based on SOEs and liberalization research literatures that are mostly focused in the African setting.

According to the statistical analysis, operating performance is significantly higher under the liberalization pressure. It means liberalization pressure improved operating performance without demanding any costs on SOEs' profitability, output, etc. And the result was interpreted along the budget constraint perspective. Theoretically, this study provided policy makers with a new perspective. Most previous studies investigated the effectiveness of privatization and of gradual reform, but the two events affect each other's' effect. The new concept 'liberalization pressure' can link between the two.

To the policy makers, this paper suggests important implications with regard to SOE and liberalization policy. First, maintaining liberalization pressure should be the core of the SOE policy. When SOE managers find ways to avoid the liberalization pressure, their budget constraints soften and their economic performance will likely to decline. Second, the pressure comes from actual liberalization and privatization threats. This thesis defined the Hellen's Administration as a period when the government planned liberalization and privatization programs, announced issues concerning SOEs repeatedly, and executed liberalization in 2000-2017. These actual programs made most SOE managers worry about their performances. Third, it is preferable that liberalization pressure be more intensive at the beginning. The degree of intensity of budget constraint is a function of managers' perception. It is important that the government maintains the constant pressure on SOEs by announcing systematic reform programs and liberalization schedules and be committed to it. In other words, it is crucial that government alter the rents of manager and employees of SOEs. Thus, to renew the perception of managers, continuing pressure is needed.

When this policy is implemented, most of the social costs (disorder and opposition) would occur at the early stages, while the social benefits (efficient public sector) will occur over a long period of time. The role of policy entrepreneurs and leaders is to overcome short-term pain and utilize the long-term gain which tends to be much larger in the case of SOE reform.

\section{References}

Abbott, LJ, Susan Parker, and Gary F. Peters, 2002. The Audit Committee Characteristics and Financial Statement: A Study of the Efficacy of Certain Blue Ribbon Committee Recommendation. Working paper. www.ssrn.com

Bozec, Richard, Gaetan Breton and Louise Cote, (2002), The Performance of State owned Enterprises Revisited, Financial Accountability and Management, 18(4): 383-407.

Chen, V.Z. et al. (2018). A Principals-Principals Perspective of Hybrid Leviathans: Cross-Border Acquisitions by State-Owned MNEs. Journal of Management. University of North Carolina at Charlotte

Christiansen, H. (2011), - The Size and Composition of the SOE Sector in OECD Countriesll, OECD Corporate Governance Working Papers, No. 5, OECD Publishing, available at: http://dx.doi.org/10.1787/5kg54cwps0s3-en.

Efird, N. (2010). The State-Owned Enterprise as a Vehicle for Stability. Strategic Studies Institute. http://smallbusiness.chron.com/strategic-management-needed-61313.html. Accessed [July 5, 2018].

Fourie, D.J., (2001). The restructuring of state-owned enterprises: South African initiatives. Asian Journal of 
Public Administration, 23(2), pp. 205-216.

Friedmann W. and Garner J. F. (1970) Government Enterprises: A Comparative Study, London: Sevens.

Hervani, A. A., Helms, M. M., \& Sarkis, J. (2005). Performance measurement for green supply chain management. Benchmarking: An international journal, 12(4), 330-353.

Kephart, J. O., \& Chess, D. M. (2003). The vision of autonomic computing. Computer, 36(1), 41-50.

Kim, Junki. (2017). Policies on Reform and Privatization of SOEs (in Korean), 25

Kornai, Janos, (1979). Resource-constrained versus Demand-constrained System, Journal of Economic Literature, 24(4): 681-737.

Kornai, Janos, (1980). Economics of Shortage, Amsterdam: North-Holland.

Kornai, Janos, (1992). The Socialist System: The Political Economy of Communism, Oxford: Oxford University Press.

Magginson, William L., Robert C. Nash, and Mattias van Randerbough, (1994), The Financial and Operating Performance of Newly Privatized Firms: An International Empirical Analysis, The Journal of Finance, 49(2): 403-452.

Maskin, Eric and Chenggang Xu, (2001). Soft Budget Constraint Theories: From centralization to the market, Economics of Transition, 9(1): 1-27.

Massey, D. (2013). Space, place and gender. John Wiley \& Sons.

Nguyen, L. D., \& Mujtaba, B. G. (2011). Stress, Task, and Relationship Orientations of Vietnamese: An Examination of Gender, Age, and Government Work Experience in the Asian Culture. In Competition Forum (Vol. 9, No. 2, p. 235). American Society for Competitiveness.

Organization for Economic Cooperation and Development. (2005), Paris Declaration and Accra Agenda for Action. OECD. Retrieved from http://www.oecd.org/dac/effectiveness/34428351.pdf

Owned Enterprises in the Global Economy: Reason for Concern? VOX: CEPR's Policy Portal. 2 May. http://voxeu.org/article/state-owned-enterprisesglobal-economy-reason-concern (accessed 21 December 2017).

Sutiyono, W. (2007). Human resource management in state-owned and private enterprises in Indonesia. Bulletin of Indonesian Economic Studies, 43(3), 377-394.

Sutiyono, W. (2007). Human resource management in state-owned and private enterprises in Indonesia. Bulletin of Indonesian Economic Studies, 43(3), 377-394.

Wei, Zuobao, Oscar Varela, Juliet D’Souza, and M. Kabir Hassan, (2003). The Financial and Operating Performance of China's Newly Privatized Firms, Financial Management, 32(2): 107-126 